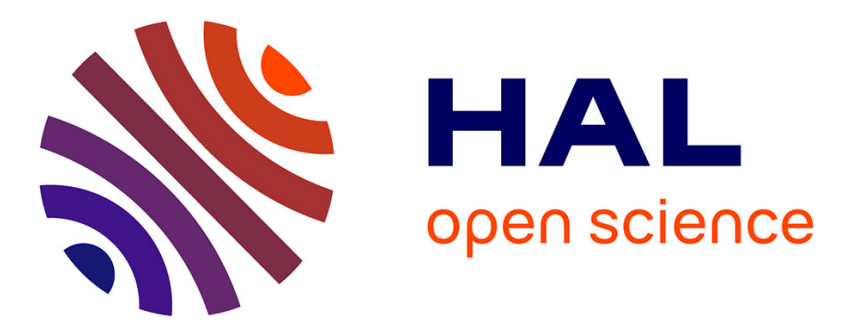

\title{
Intercomparison between TRIO-EF and IMPACT codes with reference to experimental strontium migration data.
}

L. Trotignon, M-H. Faure, A. Stietel, C. Riglet-Martial, M. Sardin, P. Vitorge, F. Lefevre

\section{To cite this version:}

L. Trotignon, M-H. Faure, A. Stietel, C. Riglet-Martial, M. Sardin, et al.. Intercomparison between TRIO-EF and IMPACT codes with reference to experimental strontium migration data.. Journal of Contaminant Hydrology, 1997, 26 (1-4), pp.279-289. 10.1016/S0169-7722(96)00075-7 . cea-02359281

\section{HAL Id: cea-02359281 https://hal-cea.archives-ouvertes.fr/cea-02359281}

Submitted on 12 Nov 2019

HAL is a multi-disciplinary open access archive for the deposit and dissemination of scientific research documents, whether they are published or not. The documents may come from teaching and research institutions in France or abroad, or from public or private research centers.
L'archive ouverte pluridisciplinaire HAL, est destinée au dépôt et à la diffusion de documents scientifiques de niveau recherche, publiés ou non, émanant des établissements d'enseignement et de recherche français ou étrangers, des laboratoires publics ou privés. 


\section{C3MI : CEA-CNRS CODE OF MIGRATION INTERCOMPARISON}

Laurent Trotignon, Chantal Riglet-Martial, CEA DCC/DESD/SESD/Section de Géosciences et d'Expérimentations, C.E. Cadarache, 13108 Saint-Paul-lezDurance Cedex, France.

Anne Stietel, CEA DRN/DMT/SEMT/Laboratoire TTMF, C.E. Saclay, 91191 Gif-surYvette Cedex, France.

Michel Sardin, CNRS-LSGC-ENSIC, 1, rue Grandville, BP 451, 54001 Nancy Cedex, France.

France Lefèvre, Marie-Hélène Fauré, Pierre Vitorge. CEA DCC/DESD/SESD/Section de GéoChimie, C.E. Fontenay-aux-Roses, BP6, 92265 Fontenay-aux-Roses Cedex, France.

\section{ABSTRACT}

This work presents an intercomparison exercice between two geochemical migration codes, TRIO-EF (object oriented finite element code) and IMPACT (chemical engineering code). The predictions of the two codes are compared with reference experimental results obtained in a previous study of strontium transport in soil columns. This simulated geochemical system is well documented and includes ion exchange, dissolution-precipitation and complexation reactions. Solution transport is simulated by a one dimensional convection-dispersion model. The predictions of TRIO-EF and IMPACT are both in good agreement with experimental results. Slight differences are nevertheless observed between the two codes especially when concentrations discontinuities are involved such as in boundary conditions or precipitation fronts. These discrepancies between the two codes can mainly be attributed to the different discretization approaches. Further intercomparison exercices are planned for more complex geochemical systems, e.g. migration of $\mathrm{Am}, \mathrm{Np}$ or $\mathrm{Pu}$.

\section{INTRODUCTION}

Early predictions of radioelement migration often used a partition coefficient, so called $\mathrm{K}_{\mathrm{d}}$, to account for the chemical reactions (sorption, ion exchange, ...) occuring during transport. The $\mathrm{K}_{d}$ is generally assumed to be constant but this hypothesis is invalid in most cases. Recent predictive migration models include a more realistic description of these chemical phenomena. They yet require an experimental validation. Indeed, simple cases were analytical solutions are available are important tests for such numerically coded models, but are not enough for thorough validation and consolidation of predictions. Two main areas may be considered : i) validation of conceptual models, ii) comparison of predictions for the same conceptual model by different codes. The aim of this work is to compare, on the basis of dedicated migration experiments, the predictions of two migration codes. Reference migration experiments were designed in order to display multiple physicochemical phenomena (ion exchange, complexation and precipitation) for a well documented chemical system. Previous work (Lefèvre et al., 1993) already included IMPACT computations because this code is very convenient for modelling column experiments. The two codes used in the present exercice, TRIO-EF and IMPACT, adopt a macroscopic point of view to describe the porous medium (global dispersion coefficient, ...) but resolve the migration problem with different numerical methods. Such a comparison provides thus important information for migration codes users and developpers in the fields of time and space discretization, boundary conditions formulation, sensitivity to model parameters. In the first part of the paper, a recall of experimental results and a summary of the conceptual 
model are given. In the next part, a description of the two migration codes used in this exercice is made. The predictions of the two codes are then compared and discussed.

\section{PRESENTATION OF REFERENCE EXPERIMENTS}

All experimental work presented here was already discussed in previous papers (Lefèvre et al. , 1993, 1994). Among these results, two experiments were chosen as reference experiments for the intercomparison. Main results of reference experiments and conceptual model parameters chosen for the TRIO-IMPACT intercomparison are now presented.

\subsection{EXPERIMENTS}

The two reference experiments are described in Lefèvre et al. (1993). The soil sample (Güe sand) used for transport experiments is a clayey sand with small amounts of calcite. The column is, in a first stage, equilibrated with deionized water or a $\mathrm{CaCl}_{2}$ solution. A definite volume of a solution containing strontium is then injected in the column. After this second stage, the composition of the feeding solution is changed in order to elute the fixed strontium. The SOLEX experiment involves ion exchange phenomena as well as dissolutionprecipitation reactions. In the IONEX experiment, dissolution and precipitation of $\mathrm{SrCO}_{3}$ are not potent and retardation of strontium occurs only because of ion exchange phenomena. Experimental conditions are summarized in Table 1.

\subsection{CHEMICAL MODEL}

Calcite dissolution, strontianite precipitation or dissolution and $\mathrm{Ca}^{++} / \mathrm{Sr}^{++}$cationic exchange on clays have been identified as the main reactions governing strontium transport in the soil columns. In addition to these solid-solution interactions, the chemical model used in this work also includes carbonic acid equilibria and water dissociation. Pre-equilibration of the columns with deionized water leads to a pH around 9.8 that is consistent with calcitewater equilibrium in a closed system. Solutes of $\mathrm{Ca}$ and $\mathrm{Sr}$ are injected as chloride salts and $\mathrm{Cl}^{-}$is considered to be a non reactive species. Aqueous complexes of $\mathrm{Ca}^{++}$or $\mathrm{Sr}^{++}$with $\mathrm{HCO}_{3}{ }^{-}, \mathrm{CO}_{3}^{--}$are not taken into account in this model and we verified that they were negligible by comparison with $\mathrm{Ca}^{++}$and $\mathrm{HCO}_{3}{ }^{-}$. Feed solutions are in thermodynamic equilibrium with atmospheric $\mathrm{CO}_{2}$. before injection. In the saturated porous medium there is however no longer equilibration with atmospheric $\mathrm{CO}_{2}$. Phases are in local thermodynamic equilibrium at a constant temperature. The speciation model is summarized in Table 2.

\subsection{TRANSPORT MODEL}

The transport model is based on the assumptions that the fluid flow is steady and one-dimensional ( $\vec{U}$ is the pore velocity of the fluid $\left(\mathrm{ms}^{-1}\right)$ corresponding to a fluid flow of 1 $\mathrm{ml} / \mathrm{min}$.). The diffusion-dispersion factor, $D\left(\mathrm{~m}^{2} \mathrm{~s}^{-1}\right)$ is constant. The Peclet number of the fluid flow, $\mathrm{Pe}=\mathrm{UL} / \mathrm{D}$ where $\mathrm{L}$ is the column length is large $(\sim 200)$ which means that the transport of aqueous species is dominantly convective. In IMPACT, the dispersion process is represented by the model of mixing cells in series. The number of mixing cells $\mathrm{J}$ is directly linked to Pe by the relation (Villermaux, 1982) :

$$
\mathrm{Pe}=2(\mathrm{~J}-1)
$$

In TRIO, the coefficient $D$ is defined in the dispersion operator used in the transport equation. Table 3 summarizes the main hydrodynamic parameters adopted for the computations. The pore volume, $\mathrm{Vp}$, and Peclet number of the column, $\mathrm{Pe}$, were determined experimentally by non reactive tracer injections (Lefèvre et al., 1993).

\subsection{RESULTS OF REFERENCE EXPERIMENTS}

Table 4 reports, for the two reference experiments, the measures of the dissolved concentration of $\mathrm{Sr}$ and $\mathrm{Ca}$. The relative uncertainity on experimental results is estimated to be less than $10 \%$. There is no experimental data on the spatial repartition of chemical elements in the column. Such information could be obtained by the use of radioactive tracers 
or by other non destructive methods. Migration codes can however give representations of the column state (distribution of $\mathrm{SrCO}_{3}, \ldots$ ) at different moments and guide further experimental investigations.

\section{PRESENTATION OF TRIO-EF AND IMPACT MIGRATION CODES 3.1 CODES}

Both codes were run on an IBM ${ }^{\oplus} \mathrm{RS} 6000$ station.

\section{TRIO-EF}

TRIO-EF is an object-oriented finite element code that is developped at the CEA for the numerical modelling of thermohydraulic phenomena, atmospheric dispersion and hydrogeology. It is possible to simulate stationnary or transient fluid flow in 1-D, 2-D or 3-D space domains. Recent evolutions of TRIO-EF in the field of earth-sciences include the developpement of an algorithm coupling solute transport by diffusion or advection with chemical transformations (Chupeau, 1991 ; Abdennour-Pfiffer, 1994). The user builds its own instruction set and may include, if necessary, coupling with the evolution of temperature or permeability fields during transport-chemistry calculations. The chemical module used in TRIO is derived from the geochemical code MINEQL (Westall et al., 1976 ; Schweingruber, 1984). At present time, this equilibrium chemical model is able to take into account, in addition to solution complexation and dissolution-precipitation reactions, sorption and ionexchange phenomena. Temperature dependance of equilibrium constants may be taken into account for space or time dependant temperature fields. The ion strength dependance of solute activity coefficients is described by the classical Davies approximation (Morel and Hering, 1993). The migration problem is solved by a two-step algorithm (Yeh and Tripathi, 1989 ; Abdennour-Pfiffer, 1994), in which equations describing transport and chemical speciation are solved iteratively between time step p-1 and time step p. At present time, reaction kinetics are not included in the model.

\section{IMPACT}

\subsection{SPATIAL AND TEMPORAL DISCRETIZATION - BOUNDARY CONDITIONS}

For TRIO-EF calculations, the column was discretized in 234 elements of equal length $(\mathrm{dx}=0.5 \mathrm{~mm})$ and the time step was kept constant $(\mathrm{dt}=3 \mathrm{~s})$. Other settings were also tried, in particular with variable time steps during calculation (from $0.6 \mathrm{~s}$ to $15 \mathrm{~s}$ ) and with elements of increasing size (from 0.2 to $0.8 \mathrm{~mm}$ ) along the column. These trials were made in order to obtain a better description of steep fronts and of boundary conditions switching at the column head. However time step increases during calculation must be progressive in order to avoid numerical artifacts as local redistribution of precipitates. This is why the first setting described above was finally found to be a simple and reasonnable compromise. The boundary condition describing the input solution was applied to the first node of the column.

For IMPACT, the number of mixing cells is directly linked to the dispersion coefficient (Eq. 1) and was determined to be $\mathrm{J}=100$. The time step is variable during computation. In particular time steps decrease strongly during the dissolution of $\mathrm{SrCO}_{3}$ (SOLEX experiment).

\section{RESULTS AND DISCUSSION}

\subsection{SOLEX EXPERIMENT (ION EXCHANGE AND DISSOLUTION-PRECIPITATION)}

In this experiment, the initial injection of $\mathrm{SrCl}_{2}$ leads to the formation of $\mathrm{SrCO}_{3}$ at the head of the column. The subsequent injection of $\mathrm{CaCl}_{2}$ induces the dissolution of the $\mathrm{SrCO}_{3}$ precipitate and generates a strong Sr pulse that migrates through the column (Table 4 and Lefèvre et al., 1993). The evolution of Sr concentration at the column outlet is represented as a function of delivered volume (equivalent to time) in Fig. 1a. The two computations and experimental data are in fair agreement. Small differences between the TRIO-EF and 
IMPACT curves may be noted : i) the maximum Sr concentration is observed slightly earlier with TRIO-EF, ii) the maximum Sr concentration is $10 \%$ less in TRIO-EF's prediction than for IMPACT, iii) the Sr distribution is more spread out in time for TRIO-EF. In both cases however, the ratio of restituted $\mathrm{Sr}$ to injected $\mathrm{Sr}$ at $8 \mathrm{Vp}$ is comprised between 0.999 and 1 . It was found that, for too large values of $\mathrm{dx}$ and $\mathrm{dt}$, the $\mathrm{Sr}$ distribution predicted by TRIO-EF could be sensitive to discretization parameters, although $\mathrm{dt}$ and $\mathrm{dx}$ remained in the theoretical limits imposed by finite element discretization. Preliminary tests identified possible causes for this behaviour : i) loss of some $\mathrm{Sr}$ at the switching of boundary conditions when $\mathrm{dx}$ is large at the column head, due to finite element interpolation, ii) existence of some numerical dispersion for reactive components. Further investigations on this phenomenon are needed. At the outlet of the column, the predicted evolutions of $\mathrm{Cl}$ - concentration as a function of delivered volume are in very good agreement (Fig. 1b). The difference in $\mathrm{pH}$ curves after $3 \mathrm{Vp}$ (Fig. 1b) originates from the different treatment of activity coefficients of charged species in IMPACT (no ionic strength correction) and TRIO-EF (Davies approximation for activity coefficients). A first order correction made on IMPACT simulation results accounted correctly for this $\mathrm{pH}$ gap. The predictions by the two codes for the distribution of chemical species at the head of the column (first mixing cell for IMPACT, second node for TRIO-EF) as a function of delivered volume are also in good agreement (Fig. $2 \mathrm{a}$ and $2 \mathrm{~b}$ ) $\mathrm{SrCO}_{3}$ precipitates at the head of the column during the initial injection (see Table 1) and dissolves at the eluant change at $2 \mathrm{Vp}$. Differences in produced $\mathrm{SrCO}_{3}$ quantity and time at which precipitation starts are due to the difference in spatial discretization in the two codes. Nevertheless, the predictions of final Sr restitution (Fig. 1) are close. Fig. 3 compares the spatial distribution of chemical species in the column at a time corresponding to injection of $2.23 \mathrm{Vp}$ of feed solution, i. e. just after the dissolution of $\mathrm{SrCO}_{3}$. At this stage, the $\mathrm{Sr}^{++}$pulses are in very good agreement. At final restitution (Fig. 1), larger differences between the two predictions for $\mathrm{Sr}^{++}$are observed. As already mentionned, this could indicate a slight numerical dispersion for reactive species in TRIO-EF.

\subsection{IONEX EXPERIMENT (ION-EXCHANGE - NO PRECIPITATION)}

In this experiment precipitation of $\mathrm{SrCO}_{3}$ does not occur and retardation of $\mathrm{Sr}$ migration occurs only because of ion exchange phenomena (Table 1 . The agreement between TRIOEF and IMPACT predictions and experimental data for Sr elution (Fig. 4a) is good. Slight differences can be noted between the two codes : i) the rise of the elution peak is about 0.05 $\mathrm{Vp}$ earlier for TRIO-EF, ii) the maximum $\mathrm{Sr}^{++}$eluted concentration is about $1 \%$ less in the TRIO-EF prediction. The comparison between TRIO-EF and IMPACT predictions for the spatial $\mathrm{Sr}^{++}$distribution after the injection of $3 \mathrm{Vp}$ of solution are shown in Fig. 4b.

\section{CONCLUSION}

This migration code intercomparison exercice involved two codes that follow very different approaches for modelling solute transport and coupling of transport with chemical transformations. The agreement between these two codes, IMPACT and TRIO-EF, for the modelling of 1-D migration phenomena involving ion-exchange, dissolution-precipitation and complexation reactions is nevertheless good. Differences in the codes predictions are often related to differences in discretization schemes and can be easily accounted for. The comparison of predictions for the migration of strongly reactive elements like $\mathrm{Sr}$ is fair (SOLEX experiment) or excellent (IONEX experiment) but desserves further numerical investigations. Further intercomparison exercices are prepared in relation with experimental work on more complex chemical systems involving the migration of $\mathrm{Am}, \mathrm{Np}$ and $\mathrm{Pu}$. 


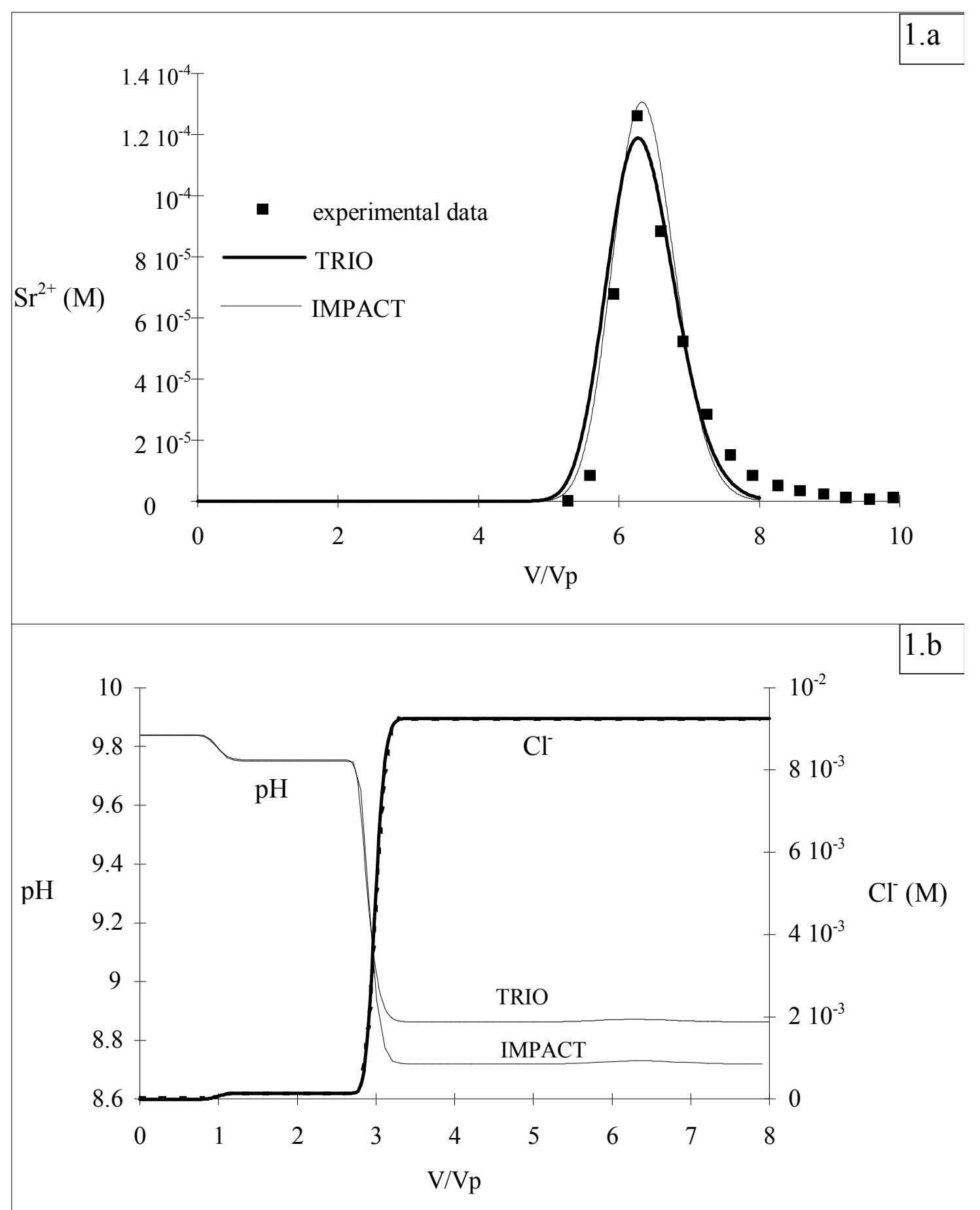

Figures 1 
Page 6 -24/08/1995

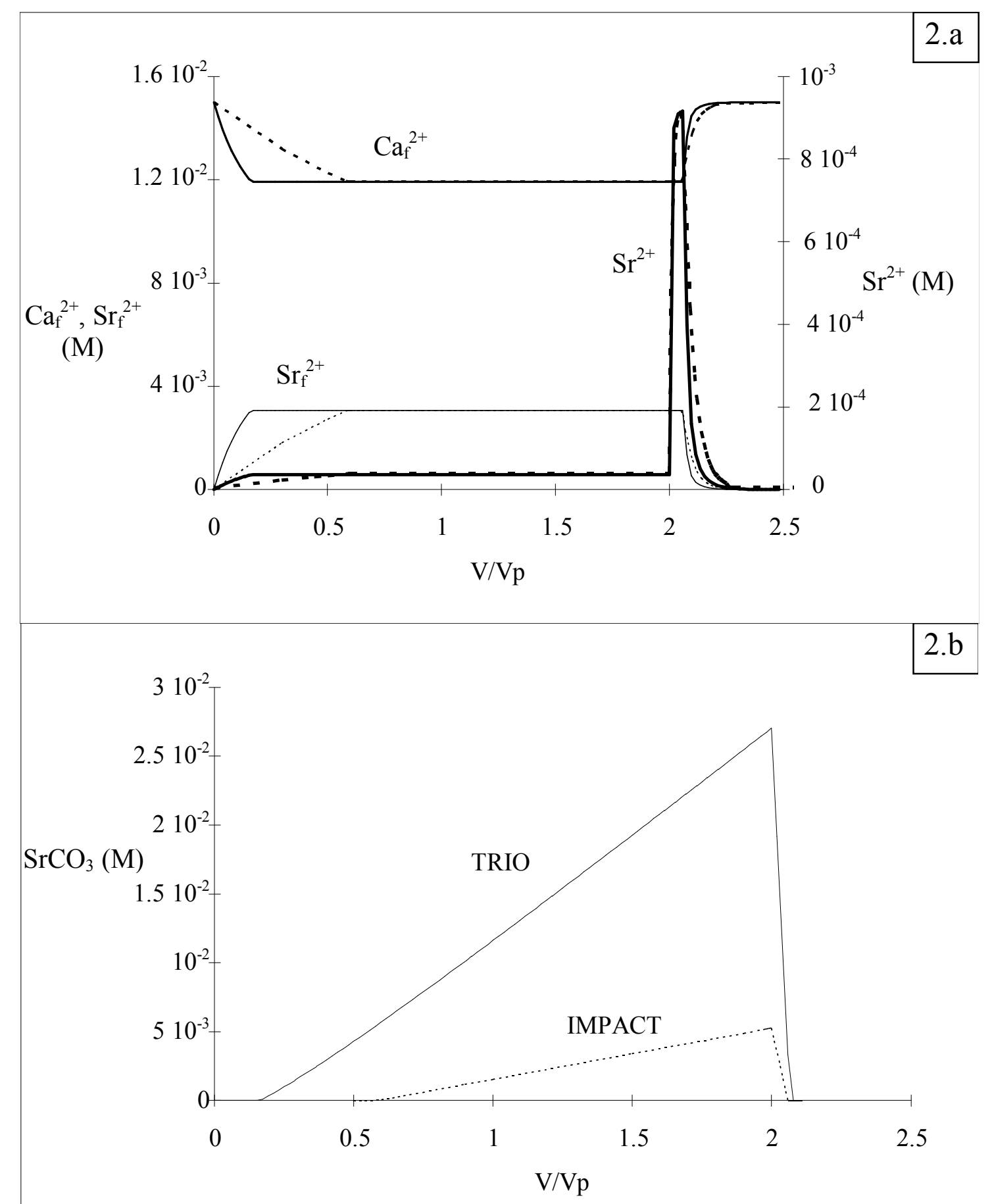

Figures 2 
Page 7 -24/08/1995

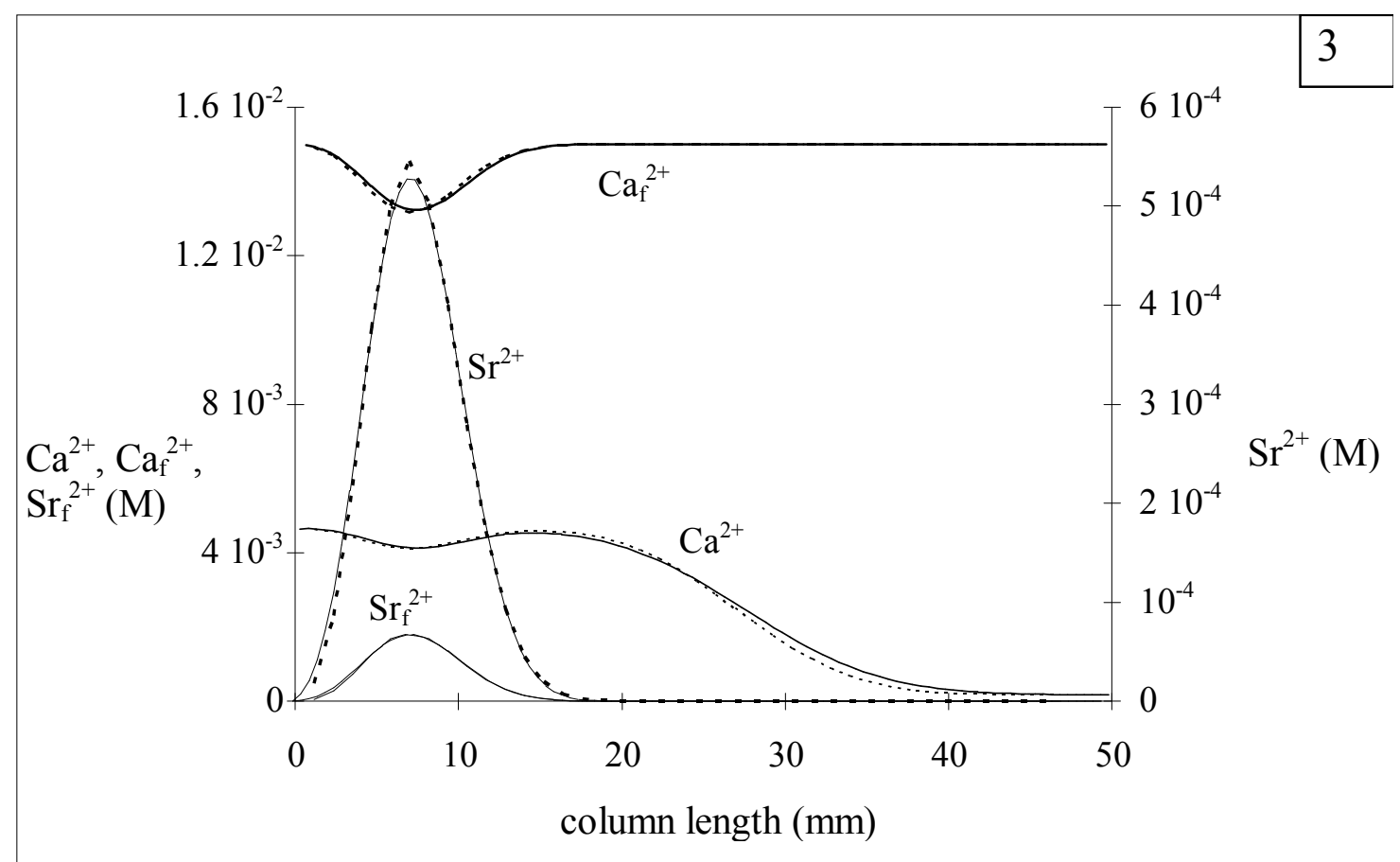

Figure 3 
Page 8 -24/08/1995
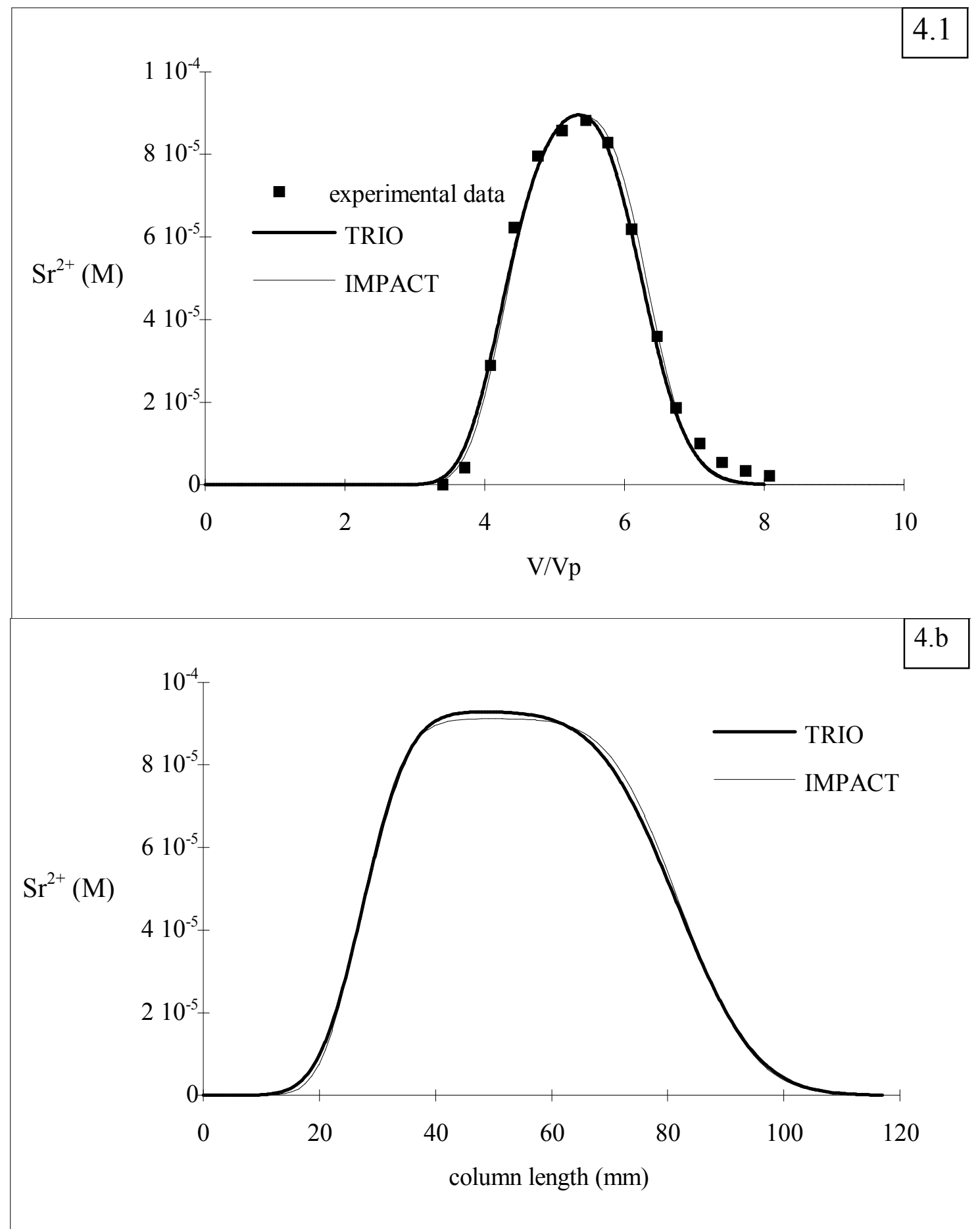

Figures 4 
Table 1:

\begin{tabular}{|c|c|c|c|c|}
\hline experiment & $\begin{array}{c}\text { preequilibrating } \\
\text { solution }\end{array}$ & \multicolumn{2}{|c|}{ injection solution } & \multirow{2}{*}{$\begin{array}{c}\text { elution } \\
\text { solution }\end{array}$} \\
\cline { 3 - 4 } & wolume & composition & \\
\hline exp1 & water & $2 \mathrm{~V}_{\mathrm{p}}$ & $\mathrm{SrCl}_{2} 7.1510^{-5} \mathrm{M}$ & $\mathrm{CaCl}_{2} 4.6310^{-3} \mathrm{M}$ \\
exp2 & $\mathrm{CaCl}_{2} 4.6910^{-3} \mathrm{M}$ & $2 \mathrm{~V}_{\mathrm{p}}$ & $\mathrm{SrCl}_{2} 9.310^{-5} \mathrm{M}$ & $\mathrm{CaCl}_{2} 4.6910^{-3} \mathrm{M}$ \\
& & & $\mathrm{CaCl}_{2} 4.6910^{-3} \mathrm{M}$ & \\
\hline
\end{tabular}

Table 2:

\begin{tabular}{|l|l|}
\hline Reactions & Equilibrium constant \\
\hline $\mathrm{H}_{2} \mathrm{O} \Leftrightarrow \mathrm{H}^{+}+\mathrm{OH}^{-}$ & $\mathrm{K}_{\mathrm{w}}=10^{-14}$ \\
$\mathrm{H}_{2} \mathrm{CO}_{3} \Leftrightarrow \mathrm{HCO}_{3}^{-}+\mathrm{H}^{+}$ & $\mathrm{K}_{1}=10^{-6.3}$ \\
$\mathrm{HCO}_{3}{ }^{-} \Leftrightarrow \mathrm{CO}_{3}{ }^{2-}+\mathrm{H}^{+}$ & $\mathrm{K}_{2}=10^{-10.3}$ \\
$\mathrm{CaCO}_{3 \mathrm{~s}} \Leftrightarrow \mathrm{Ca}^{2+}+\mathrm{CO}_{3}{ }^{2-}$ & $\mathrm{K}_{\mathrm{s} 1}=10^{-8.42}$ \\
$\mathrm{SrCO}_{3 \mathrm{~s}} \Leftrightarrow \mathrm{Sr}^{2+}+\mathrm{CO}_{3}{ }^{2-}$ & $\mathrm{K}_{\mathrm{s} 2=10^{-9.03}}$ \\
$\mathrm{Ca}_{\mathrm{f}}{ }^{2+}+\mathrm{Sr}^{2+} \Leftrightarrow \mathrm{Ca}^{2+}+\mathrm{Sr}_{\mathrm{f}}{ }^{2+}$ & $\mathrm{K}_{\mathrm{Sr} / \mathrm{Ca}}=1.05$ \\
\hline
\end{tabular}

Table 3:

\begin{tabular}{|c|c|c|c|c|c|c|}
\hline $\begin{array}{c}\text { diameter } \\
(\mathrm{mm})\end{array}$ & $\begin{array}{c}\text { length } \\
(\mathrm{mm})\end{array}$ & $\begin{array}{c}\text { M. sand } \\
(\mathrm{g})\end{array}$ & $\mathrm{V}_{\mathrm{p}}(\mathrm{ml})$ & $\begin{array}{c}\text { CEC } \\
(\mathrm{eq} / \mathrm{l})\end{array}$ & $\begin{array}{c}\text { flow rate } \\
(\mathrm{ml} / \mathrm{mn})\end{array}$ & $\mathrm{Pe}=\frac{\mathrm{uL}}{\mathrm{D}}$ \\
\hline 25.4 & 117 & 94 & 26 & 0.03 & 1 & 198 \\
\hline
\end{tabular}


Table 4:

\begin{tabular}{|c|c|c|c|c|c|}
\hline \multicolumn{3}{|c|}{ SOLEX Experiment } & \multicolumn{3}{|c|}{ IONEX Experiment } \\
\hline $\mathrm{V} / \mathrm{V}_{\mathrm{p}}$ & $\mathrm{Sr}^{2+}(\mathrm{M})$ & $\mathrm{Ca}^{2+}(\mathrm{M})$ & $\mathrm{V} / \mathrm{V}_{\mathrm{p}}$ & $\mathrm{Sr}^{2+}(\mathrm{M})$ & $\mathrm{Ca}^{2+}(\mathrm{M})$ \\
\hline 0.33 & 0 & & 0.34 & 0 & $4.8410^{-3}$ \\
\hline 0.66 & 0 & $5.0710^{-5}$ & 0.68 & 0 & $4.6910^{-3}$ \\
\hline 0.99 & 0 & $5.5510^{-5}$ & 1.02 & 0 & $4.7310^{-3}$ \\
\hline 1.32 & 0 & $9.8710^{-5}$ & 1.39 & 0 & $4.8810^{-3}$ \\
\hline 1.65 & 0 & $1.1210^{-4}$ & 1.70 & 0 & $4.7910^{-3}$ \\
\hline 1.96 & 0 & $1.0710^{-4}$ & 2.03 & 0 & $4.8110^{-3}$ \\
\hline 2.29 & 0 & $9.8910^{-5}$ & 2.38 & 0 & $4.8610^{-3}$ \\
\hline 2.62 & 0 & $9.9310^{-5}$ & 2.71 & 0 & $4.7710^{-3}$ \\
\hline 2.95 & 0 & $1.1110^{-4}$ & 3.05 & 0 & $4.8510^{-3}$ \\
\hline 3.28 & 0 & $2.6910^{-3}$ & 3.40 & 0 & $4.7710^{-3}$ \\
\hline 3.61 & 0 & $4.7510^{-3}$ & 3.72 & $4.2510^{-6}$ & $4.7910^{-3}$ \\
\hline 3.94 & 0 & $4.6810^{-3}$ & 4.07 & $2.9110^{-5}$ & $4.7010^{-3}$ \\
\hline 4.27 & 0 & $4.7510^{-3}$ & 4.41 & $6.2210^{-5}$ & $4.7910^{-3}$ \\
\hline 4.6 & 0 & $4.7310^{-3}$ & 4.75 & $7.9510^{-5}$ & $4.7610^{-3}$ \\
\hline 4.93 & 0 & $4.7310^{-3}$ & 5.09 & $8.5810^{-5}$ & $4.9010^{-3}$ \\
\hline 5.26 & 0 & $4.7310^{-3}$ & 5.43 & $8.8410^{-5}$ & $4.7910^{-3}$ \\
\hline 5.59 & $8.5010^{-6}$ & $4.7810^{-3}$ & 5.77 & $8.2810^{-5}$ & $4.8010^{-3}$ \\
\hline 5.93 & $6.8210^{-5}$ & $4.6810^{-3}$ & 6.11 & $6.1810^{-5}$ & $4.6910^{-3}$ \\
\hline 6.26 & $1.2610^{-4}$ & $4.6510^{-3}$ & 6.45 & $3.6110^{-5}$ & $4.8410^{-3}$ \\
\hline 6.59 & $8.8710^{-5}$ & $4.6410^{-3}$ & 6.73 & $1.8810^{-5}$ & $4.7910^{-3}$ \\
\hline 6.92 & $5.2610^{-5}$ & $4.6210^{-3}$ & 7.07 & $1.0110^{-5}$ & $4.9910^{-3}$ \\
\hline 7.25 & $2.8810^{-5}$ & $4.7010^{-3}$ & 7.39 & $5.5710^{-6}$ & $4.9310^{-3}$ \\
\hline 7.58 & $1.5510^{-5}$ & $4.6610^{-3}$ & 7.73 & $3.3710^{-6}$ & $5.1810^{-3}$ \\
\hline 7.91 & $8.8210^{-6}$ & $4.6610^{-3}$ & 8.06 & $2.1810^{-6}$ & $5.1810^{-3}$ \\
\hline 8.25 & $5.2710^{-6}$ & $4.6610^{-3}$ & & & \\
\hline 8.58 & $3.3810^{-6}$ & $4.6410^{-3}$ & & & \\
\hline 8.91 & $2.2510^{-6}$ & $4.7010^{-3}$ & & & \\
\hline 9.23 & $1.4610^{-6}$ & $4.6910^{-3}$ & & & \\
\hline 9.56 & $1.0510^{-6}$ & $4.6710^{-3}$ & & & \\
\hline 9.89 & $1.2310^{-6}$ & $4.6110^{-3}$ & & & \\
\hline
\end{tabular}




\section{REFERENCES}

ABDENNOUR-PFIFFER M. (1994) Etude hydrogéochimique et modélisation des phénomènes couplés transport-réactions liés au stockage de chaleur et/ou de déchets nucléaires dans les réservoirs géologiques. PhD Thesis - Univ. Louis Pasteur (Strasbourg I - France). 251 p.

CHUPEAU J. (1991) Contribution à l'étude théorique et expérimentale du transfert des solutés en aquifère : application au traçage chimique d'un réservoir géothermique, apports de la modélisation couplée transport-géochimie. PhD Thesis - Univ. Pierre et Marie Curie (Paris VI - France).186 p.

LEFEVRE F., SARDIN M. and SCHWEICH D. (1993) Migration of strontium in clayey and calcareous sandy soil : precipitation and ion-exchange. J. Contaminant Hydrol., 13, 215-229.

LEFEVRE F., SARDIN M. and VITORGE P. (1994) Migration of 45Ca and $90 \mathrm{Sr}$ in a clayey and calcareous sand : calculation of distribution coefficients by ion exchange theory and validation by column experiments. Fourth International Conference on the Chemistry and Migration Behaviour of Actinides and Fission Products in the Geosphere. Charleston. SC USA. Dec. 12-17, 1993. Radiochimica Acta, 711-717

MOREL F. M. M. and HERING J. G. (1993) Principles and applications of aquatic chemistry. John Wiley and Sons, New-York. 588 p.

SCHWEINGRUBER M. (1984) User's guide for extended MINEQL (EIR Version) Technical Note EIR AN-45-84-39, Swiss Federal Institute for Reactor Research.

VILLERMAUX J. (1982) Génie de la réaction chimique : conception et fonctionnement des réacteurs. Lavoisier Tec\&Doc, Paris, $401 \mathrm{pp}$.

WESTALL J. C., ZACHARY J. L. and MOREL F. M. M. (1976) MINEQL, a computer program for the calculation of chemical equilibrium composition of aqueous systems. Technical Note No18, Dpt. of Civil Enginee ring, M.I.T.

YEH G. T. and TRIPATHI V. S. (1989) A critical evaluation of recent developments in hydrogeochemical transport models of reactive multichemical components. Water Resources Research, Vol. 25, 93-108. 